\title{
FUZZY LOGIKA ALAPÚ KERETRENDSZER PARAMÉTEREINEK MEGHATÁROZÁSA
}

\section{PARAMETER DETERMINATION OF A FUZZY LOGIC- BASED FRAMEWORK}

Tóthné Laufer Edit

Óbudai Egyetem, Bánki Donát Gépész és Biztonságtechnikai Mérnöki Kar, Mechatronikai és Jármütechnikai Intézet, 1081, Hungary, Budapest, Népszínház u. 8; Telefon / Fax: +36-1-666-5377, laufer.edit@bgk.uni-obuda.hu

\begin{abstract}
During patient monitoring, personalization is extremely important in order to achieve realistic results when determining the risk level based on the measurement of physiological characteristics. This requirement can be met by a system where neither the inputs, nor their number are fixed but can be defined in a personalized way. In this article, that kind of flexible framework system is presented, with particular reference to its input factors and their measurement possibilities.
\end{abstract}

Keywords: fuzzy inference system, patient monitoring, personalization.

\section{Összefoglalás}

Páciens monitorozás során a személyre szabhatóság rendkívül fontos annak érdekében, hogy valóban reális eredményt kaphassunk, amikor az élettani jellemzők mérése alapján határozzuk meg a kockázati szintet. Ennek a követelménynek egy olyan rendszer képes megfelelni, ahol a bemenetek, és azok száma sem rögzített, hanem a konkrét személyre specifikusan határozható meg. Ebben a cikkben egy ilyen rugalmasan kezelhető keretrendszert mutatok be, különös tekintettel a bemeneti tényezők meghatározására és azok mérési lehetőségeire.

Kulcsszavak: fuzzy következtetési rendszer, páciensmonitorozás, személyre szabhatóság.

\section{Bevezetés}

Napjainkban, elsősorban az öregedő népesség problémájának köszönhetően, egyre nagyobb igény van a páciensmonitorozó rendszerekre. Rengeteg idős, krónikus betegségekkel küszködő ember tölti napjait egyedül, felügyelet nélkül, akiknél egy megfelelően kialakított rendszer akár életet is menthet. A technológiai fejlődés következtében ennek eszközháttere is biztosított. A sajnálatos sportolói tragédiák szintén rávilágítottak arra, hogy bár a sport számos kedvező hatást gyakorol a szervezetre, bizonyos esetekben káros hatásai is lehetnek. Számos, különböző elven működő mérőeszköz áll rendelkezésre, melyek segítik egy ilyen kockázat értékelő rendszer működését, akár a bemenetek rugalmas kezelhetőségét is biztosítva. A rugalmasság ebben az esetben azt jelenti, hogy maguk a bemenetek, illetve azok száma se legyen általánosan rögzített, hiszen a személyes jellemzőktől és a választott mozgásformától is nagyban függ, hogy milyen tényezök mérése szükséges. A kiértékelés során a bemenetek jellegéből adódóan a lágy 
számítási módszerek alkalmazása indokolt, mivel az élettani jellemzők esetén nem adható meg éles értékhatár [1]. Ebben a cikkben egy ilyen fuzzy logika alapú kockázatértékelő keretrendszert mutatok be a bemenetek és a mérőeszközök kiválasztására helyezve a hangsúlyt.

\section{A keretrendszer}

Az általam alkalmazott keretrendszer moduláris felépítése az 1. ábrán látható. Minden egyes alrendszer egy-egy fuzzy következtetési rendszernek tekinthető, amelyek külön-külön módosíthatók, bővíthetők. A tanulmány szempontjából az első alrendszer a legfontosabb, amely az élettani jellemzök mért értékeinek kiértékelését végzi. Itt a bemenetek, illetve azok száma személyre szabottan változtathatók az illető kórelőzményeitől, az orvosi ajánlásoktól és a választott mozgásformától függően [2].

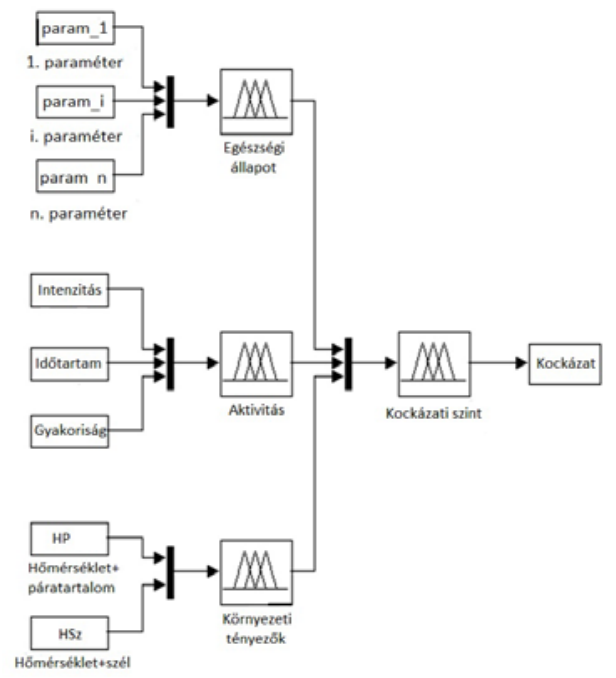

1. ábra. A rendszer felépítése

Az „Aktivitás” alrendszer a mozgás jellemzőit értékeli ki, figyelembe véve annak intenzitását, időtartamát és gyakoriságát. A „Környezeti tényezők” csoportja pedig a kültéri tevékenység esetén fontos, hiszen a höérzetet a szél, és a levegö páratartalma is befolyásolja, így a hőmérsékletnek ezekkel kombinált hatása vehető figyelembe.

Minden egyes alrendszerben Mamdani típusú következtetési rendszer végzi a kiértékelést, melyben $H A$ feltétel AKKOR következmény alakú természetes nyelvi szabályokat alkalmazunk.

\section{A bemenetek meghatározása}

A bemenetek meghatározása során, ahogy korábban is említettem, a személyes jellemzőket vesszük figyelembe. Ennek elősegítése érdekében egy személyes profilban tároljuk a páciens adatait, beleértve az egyes mozgásformák alatt monitorozandó paramétereket is. A bemenetek ugyanazon sporttevékenység során különböző páciensek esetén eltérőek lehetnek, illetve ugyanazon páciens esetén a különböző mozgásformák más tényezők figyelemmel kísérését indokolhatják, ahogy ezt az 1. táblázat is illusztrálja.

1. táblázat. Lehetséges bemeneti kombinációk 28 éves férfi páciens esetén (HRszívfrekvencia, RR-légzésszám, SBPszisztolés vérnyomás, DBP-diasztolés vérnyomás)

\begin{tabular}{|c|c|}
\hline Sporttevékenység & Bemenetek \\
\hline Futás & HR, RR \\
\hline Kerékpározás & HR, SBP, DBP \\
\hline
\end{tabular}

A bemenetek, vagyis a mérendő fiziológiás jellemzők meghatározása a személyes profilban rögzített adatok, kórelőzmények és orvosi ajánlások figyelembe vételével történik, illetve a rendelkezésre álló eszközök is befolyásolhatják azt. A legalapvetőbb, ennek következtében a leggyakrabban alkalmazott bemenet a pulzusszám, emellett a vérnyomás és a légzésszám is nagy jelentőséggel bíró tényezők. Fontos figyelembe venni azt is, hogy a kiértékelés valós időben történik, 
ezért mérlegelni kell, hogy plusz bemeneti tényezők mérése ad-e annyi plusz információt, amiért cserébe a kiértékelés lassabb lehet és a páciensnek is több korlátozást jelenthet az eszközök viselése.

\section{Mérőeszközök kiválasztása}

A mérőeszközök kiválasztásánál fontos szempont, hogy minél inkább természetes környezetet biztosítson, ne akadályozza a felhasználót a tevékenység végzése közben, ezért mindenképpen vezetéknélküli technológia alkalmazására van szükség, illetve fontos az is, hogy ne igényeljen invazív beavatkozást. A természetes környezet nem csak a kényelem szempontjából fontos, hanem bizonyos esetekben akár a mérési eredményre is hatással lehet, ha a páciens számára az eszközhasználat stresszel jár, ami egy hamis, magasabb mért értéket eredményez, értékelhetetlenné téve a kiértékelést. Ebben a cikkben a pulzusszám és a vérnyomás mérésére alkalmas eszközök választási szempontjait tekintem át.

A pulzusszám mérése különböző elveken történhet. A legegyszerübb, ugyanakkor a legkevésbé megbízható értéket a csuklón mért pulzus adja, ami az erek lüktetését, mint mechanikus ingert érzékeli. Ennél korszerübb megoldás az optikai pulzusmérés, amikor egy karpántot kell viselni, ami a bőr átvilágításával a hajszálerek tágulásából egy algoritmus segítségével számítja ki a pulzusszámot. Abban az esetben azonban, ha gyors pulzusváltozások várhatóak, nem alkalmazható ez a módszer, mert nehezen és lassan tudja követni a változást, ezért kockázat értékelés során, amikor a hirtelen változások kiszürése is fontos, nem alkalmazható biztonságosan. Ilyen eszköz a Polar cég OH1 optikai pulzusérzékelője.

A leginkább megbízható módszer, amikor egy mellkasi jeladóban lévő elektródák érzékelik a szívizom összehúzódásakor keletkező elektromos impulzust és ezt továbbítják a program számára, így EKG pontosságú értéket szolgáltatva [3]. Számos pulzusmérő van, ami ezt a technológiát használja többek között a Polar, a TomTom Runner, és a Brighton Rider. A kutatáshoz ezek közül a Polar V800-at választottam, amely vízállóságának köszönhetően akár úszás közben is használható. Az adatátvitel Bluetooth kapcsolaton keresztül történik a számítógép, illetve a mobiltelefon felé. Az automatikus vérnyomásmérök a karra helyezett mandzsetta felfújása után a leeresztés közben a brachiális artériára gyakorolt nyomást érzékelik szenzoraik segítségével, majd a szisztolés és diasztolés értékeket matematikai algoritmussal számítja ki a mérés során kapott oszcillometrikus hullámformából. Ez az algoritmus a gyártó cégtől függően változhat és ez határozza meg az eszköz pontosságát [4]. Mobiltelefonhoz is csatlakoztatható például a felkaros mérést biztosító Omron M7, illetve az iHealth BP7 csuklós vérnyomásmérő.

\section{A kiértékelés folyamata}

A kiértékelés során először a mért bemeneti értékeket fuzzifikálni kell, vagyis meg kell adnunk az egyes halmazokhoz tartozás mértékét minden egyes bemenetre, ami a vizsgált alrendszerhez tartozik. A pulzusszám esetén a tagsági függvények egy 37 éves hölgy páciens esetén a 2. ábrán láthatók, melyek (1) segítségével definiálhatók.

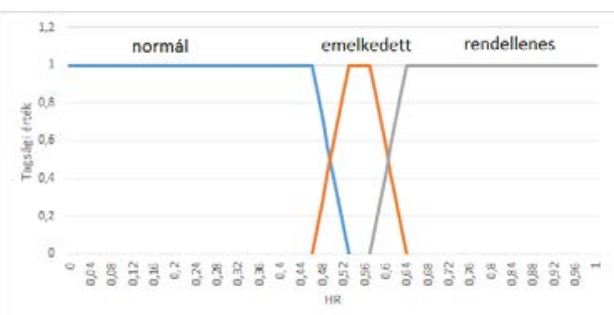

2. ábra. Bemeneti tagsági függvények 


$$
A_{i}(x)=\left\{\begin{array}{cc}
0 & x \leq a_{i} \\
\frac{x-a_{i}}{b_{i}-a_{i}} & a_{i} \leq x \leq b_{i} \\
1 & b_{i} \leq x \leq c_{i} \\
\frac{d_{i}-x}{d_{i}-c_{i}} & c_{i} \leq x \leq d_{i} \\
0 & d_{i} \leq x
\end{array}\right.
$$

ahol $a_{i}, \quad b_{i}, \quad c_{i}, d_{i}$ a tagsági függvény paraméterek, ezeket megváltoztatva a függvények a felhasználó adottságainak megfelelően a kívánt irányba tolhatók. A mérési bizonytalanságok, pontatlanságok kezelése is itt történik a paraméterek meghatározása által, mivel a függvény meredeksége, tartója és magja, ezek segítségével szabályozható.

Ezután a tüzelési szint meghatározása történik, melynek során a fuzzifikált értékeket összesítjük, általában valamilyen konjunkciós operátort alkalmazva. Esetünkben ez a szorzat operátor (2).

$$
w_{i}=\prod_{j=1}^{m} \mu_{j}(x)
$$

ahol $m$ az alrendszer bemeneteinek száma, hiszen az egyes bemenetekhez tartozó fuzzy halmazainak kombinációjából állíthatók elö a szabálypremisszák.

A kapott értékeket alkalmazzuk a Mamdani-implikáció során, annak érdekében, hogy meghatározzuk, az adott szabály milyen mértékben vesz rész a végső következtetésben. A tüzelési szintre és az adott szabályhoz tartozó konzekvens halmazra alkalmazzuk a következő összefüggést:

$$
y_{Y_{i}}=w_{i} \mu_{Y_{i}}
$$

Következő lépésként a kapott halmazokat szabályonként defuzzifikáljuk (4), majd ezeket a diszkrét értékeket aggregáljuk (5) így előállítva az összesített kockázati szintet az adott alrendszer esetén.

$$
\begin{gathered}
f_{i}=\frac{\int_{\sup \mu_{D_{i}}} \mu_{D_{i}}(y) y d y}{\int_{\sup \mu_{D_{i}}} \mu_{D_{i}}(y) d y} \\
O=\sum_{i=1}^{n} \bar{w}_{i} f_{i}=\frac{\sum_{i=1}^{n} w_{i} f_{i}}{\sum_{i=1}^{n} w_{i}}
\end{gathered}
$$

\section{Következtetések}

Páciensmonitorozó rendszerek esetén alapkövetelmény a személyre szabhatóság. Megbízható eredményt csak abban az esetben kaphatunk, ha figyelembe vesszük a páciens adottságait, kórelőzményét, orvosi ajánlásait. A bemenetek megválasztását éppen ezért rugalmasan kell kezelni. A szerző egy olyan keretrendszert fejlesztett, amely képes különböző számú és jellegü bemenet kezelésére a kiértékelés során és a választott eszközöknek köszönhetően mobiltelefonon és számítógépen egyaránt történhet a kiértékelés.

\section{Köszönetnyilvánítás}

$\mathrm{Az}$ Emberi Erőforrások Minisztériuma ÚNKP-17-4-I. kódszámú Új Nemzeti Kiválóság Programjának támogatásával készült.

\section{Szakirodalmi hivatkozások}

[1] Sieira, M. C, et al: Blood pressure response to exercise testing. Apunts Med Esport, Elsevier, 2010, 191-200 .

[2] Tóth-Laufer, E: A Flexible Fuzzy Logicbased Risk Assessment Framework. Óbuda University E-Bulletin, 6(1), 2016, 3-8.

[3] Dömötör, E: Pulzuskontroll, testsúlykontroll. Carita Bt, 2005, ISBN: 963-86741-0-5.

[4] Barbé, K, et al, D: Analyzing the Windkessel Model as a Potential Candidate for Correcting Oscillometric Blood-Pressure Measurement. IEEE TIM, Vol. 61, No. 2, 2012, 411-418 